\title{
ESTRADIOL RECEPTOR LEVELS IN RAT HYPOTHALAMIC AND LIMBIC NUCLEI ${ }^{1}$
}

\author{
THOMAS C. RAINBOW, ${ }^{2}$ BRUCE PARSONS, NEIL J. MACLUSKY,* and BRUCE S. McEWEN \\ The Rockefeller University, New York, New York 10021 and *Department of Obstetrics-Gynecology, Yale University School of \\ Medicine, New Haven, Connecticut 06510
}

Received October 29, 1981; Revised May 7, 1982; Accepted May 7, 1982

\begin{abstract}
The amount of cytoplasmic receptor for the steroid hormone, estradiol $\left(\mathrm{E}_{2}\right)$, was determined in 46 nuclei and subdivisions of rat brain. Individual nuclei were removed from $300-\mu \mathrm{m}$ frozen sections according to the punch-out method of Palkovits (Palkovits, M. (1973) Brain Res. 59: 449-450), and the content of $\mathrm{E}_{2}$ receptor was measured with a sensilive radioligand binding method. Cytoplasmic receptors for $\mathrm{E}_{2}$ were distributed heterogeneously throughout the rat brain. The highest level of receptor ( $40 \mathrm{fmol} / \mathrm{mg}$ of protein) was found in the periventricular nucleus of the preoptic area, while low $(1 \mathrm{fmol} / \mathrm{mg})$ but detectable levels of receptors were found in such limbic regions as the nucleus of the diagonal band, the olfactory tubercle, and the cingulate cortex. Regions that were devoid of detectable receptor included the medial septum, the parietal cortex, and the ventral thalamus. Our results support the notion that $\mathbf{E}_{2}$ influences reproductive behavior and neuroendocrine function by binding to receptors in discrete areas of the brain and provide the first quantitative map of $\mathrm{E}_{2}$ receptors in individual rat brain nuclei.
\end{abstract}

The brain, like peripheral organs, possesses specific intracellular receplors for the steroid hormone, $17 \beta$-estradiol $\left(\mathrm{E}_{2}\right)$ (Eisenfeld and Axelrod, 1965; McEwen and Pfaff, 1970; McEwen, 1978). These are high molecular weight molecules that move from the cytoplasm of brain cells into nuclei after $\mathrm{E}_{2}$ binds to them (Lieberburg et al., 1980). While it has been shown from gross biochemical studies that the highest concentration of $\mathrm{E}_{2}$ receptors are found in the hypothalamus and amygdala (McEwen et al., 1975) and it has been shown by in vivo autoradiography that the receptors are distributed heterogeneously within these regions (Pfaff and Keiner, 1973; Stumpf, 1968 ), the amount of $\mathrm{E}_{2}$ receptor within individual hypothalamic and limbic nuclei has never been determined by direct biochemical methods. It is important to establish both the location and relative concentration of $\mathrm{E}_{2}$ receptors in the brain because there is compelling evidence that they mediate the actions of $\mathrm{E}_{2}$ on behavior and neuroendocrine function. For example, the effects of $\mathbf{E}_{2}$ on sexual behavior or on gonadotropin secretion are correlated with the degree and duration of occupation of $\mathrm{E}_{2}$ on neural receptors (Parsons et al., 1981, 1982a; Krey

\footnotetext{
${ }^{1}$ This work was supported by National Institutes of Health Grants NS07080 and NS17435 and Institutional Grant RF7095 from the Rockefeller Foundation for research in reproductive biology. We thank Drs. N. Krieger, R. Loy, and P. Wise for their interest, and we thank Mrs. $O$. Wengerchuk for editorial assistance.

${ }^{2}$ To whom correspondence should be addressed.
}

and Parsons, 1982; McGinnis et al., 1981), and steroid and nonsteroid antagonists of receptor binding will block the actions of $\mathrm{E}_{2}$ on the brain (Arai and Gorski, 1968; Roy and Wade, 1977; Labhsetwar, 1970). In this study, we have used a sensitive radioligand binding assay to measure the amount of $\mathrm{E}_{2}$ receptor in individual nuclei of rat brain. Cytoplasmic receptors for $\mathrm{E}_{2}$ are found in a variety of brain regions in concentrations ranging from 1 to $40 \mathrm{fmol} / \mathrm{mg}$ of protein.

\section{Materials and Methods}

Animals. We assayed $\mathrm{E}_{\varepsilon}$ receptor levels in brain tissue from female Sprague-Dawley rats (180 to $220 \mathrm{gm}$; Charles River Laboratories, Wilmington, MA). The rats were ovariectomized 1 to 3 weeks before use. The animals were housed under a 12:12-hr light-dark cycle.

Microdissection of nuclei and subregions. The procedure of Palkovits (1973) was used to remove nuclei and subregions from $300-\mu \mathrm{m}$-thick frozen sections of rat brain. Rats were perfused through the heart with $20 \mathrm{ml}$ of ice cold $10 \%$ dimethyl sufoxide (DMSO), a cryoprotective agent that has been shown to protect steroid receptors from damage caused by freezing (MacLusky et al., 1982). The brains were blocked on both ends with a razor blade and frozen onto cryostat chucks in powdered dry ice. Coronal sections were cut in the König and Klippel (1963) anatomical plane using an American Optical cryostat. The microtome temperature of the cryostat was $-15^{\circ} \mathrm{C}$. 
The sections were thaw-mounted briefly onto glass slides and were stored at $-40^{\circ} \mathrm{C}$ for 24 to $72 \mathrm{hr}$ before experimental use. Using a 500- or 1000- $\mu \mathrm{m}$ hollow stainless steel tube, brain regions were removed from portions of 27 separate $300-\mu \mathrm{m}$-thick sections. These sections were cut consecutively starting from the A8380 level of the König and Klippel atlas (1963). The microdissection was done with the aid of a stereomicroscope. During the dissection, the temperature of the sections was maintained at $-15^{\circ} \mathrm{C}$ with a Cambion thermoelectrically cooled plate. The location of the nuclei and brain regions was determined from the stereotaxic atlas of König and Klippel (1963) and from the stereotaxic atlas of Palkovits (1980). The location of the microdissected regions within the 27 serially cut sections and the cannula sizes used for removal are given in Table I. In some cases, brain regions were removed with a small scalpel. In preliminary measurements on $32-\mu \mathrm{m}$ cresyl violet-stained sections, the diameter of the punch cannula did not exceed the size of the removed nuclei.

Estrogen receptor assay. We pooled tissue from three rats to obtain material for one assay. After removal from the frozen sections, the tissue samples were blown into ice cold plastic tubes. containing $24 \mu \mathrm{l}$ of TEGD buffer (10 mM Tris- $\mathrm{HCl}, 5 \mathrm{~mm}$ EDTA, $10 \%$ glycerol, and $1 \mathrm{~mm}$ dithiothreitol, $\mathrm{pH}$ 7.4). The tissue was homogenized at moderate speed with a motor-driven homogenizer (10 strokes, up and down), and the cytosol fraction of the homogenate was obtained by centrifugation in a Beckman Airfuge at $100,000 \times \mathrm{g}$ for $20 \mathrm{~min}$. One hundred microliters of the cylosol was added to $50 \mu \mathrm{l}$ of TEGD buffer that contained either sufficient $\left[{ }^{3} \mathrm{H}\right]$ estradiol $([2$, $4,6,7{ }^{3} \mathrm{H}(\mathrm{N})$ ]estradiol, 115 or $140 \mathrm{Ci} / \mathrm{mmol}$, New England Nuclear) to make a final concentration of $1 \mathrm{nM}\left[{ }^{3} \mathrm{H}\right] \mathrm{E}_{2}$ or $1 \mathrm{nM}\left[{ }^{3} \mathrm{H}\right] \mathrm{E}_{2}$ along with $1 \mu \mathrm{M}$ moxestrol to determine nonspecific binding. Aliquots of the cytosol were incubated with $\left[{ }^{3} \mathrm{H}\right] \mathrm{E}_{2}$ for $4 \mathrm{hr}$ at $4^{\circ} \mathrm{C}$ in plastic microcentrifuge tubes. The $\left[{ }^{3} \mathrm{H}\right] \mathrm{E}_{2}$ bound to receptors was separated from free ligand by gel filtration at $4{ }^{\circ} \mathrm{C}$ on Sephadex LH20 columns. The columns were made from 1-ml plastic disposable micropipete tips, which were filled to $5 / 6$ of the total volume with Sephadex LH-20 (Pharmacia) equilibrated with $10 \mathrm{~mm}$ Tris-HCl, $5 \mathrm{~mm}$ EDTA, and $10 \%$ glycerol, pH 7.4 (TEG buffer). The columns were stoppered with a glass bead. The columns were first washed with $200 \mu \mathrm{l}$ of TEGD. At $15 \mathrm{~min}$ after the TEGD wash, $100-\mu \mathrm{l}$ aliquots of the incubates were applied to the columns and were washed onto the column bed with an additional $100 \mu \mathrm{l}$ of TEGD. At $30 \mathrm{~min}$ after the samples were applied, the $\left[{ }^{3} \mathrm{H}\right] \mathrm{E}_{2}$ bound to receptors was eluted from the columns with $400 \mu \mathrm{l}$ of TEG buffer. The radioactivity in the eluate was measured by liquid scintillation counting using Liquiscint scintillation fluid (National Diagnostics, Somerville, NJ) at $32 \%$ efficiency. The protein content of the incubate was determined by the dyebinding method of Bradford (1976). All results were expressed as femtomoles of $\mathrm{E}_{2}$ specifically bound to receptors per mg of protein.

To evaluate any loss of receptors caused by freezing, we used Scatchard analysis to compare $\mathrm{E}_{2}$ receptors from DMSO-perfused and frozen samples of mediobasal hypothalamus-preoptic area (MBH-POA) to unperfused tissue assayed immediately after sacrifice. The MBHPOA samples were removed as described (McEwen et al., 1975). The tissue was either assayed immediately for receptor levels or was frozen on dry ice and then kept at $-15^{\circ} \mathrm{C}$ for $2 \mathrm{hr}$ to approximate the treatment that sectioned tissue received. The frozen tissue then was stored overnight at $-40^{\circ} \mathrm{C}$. Tissue from three or four rats was pooled for analysis and was homogenized in 2.8 or $3.5 \mathrm{ml}$ of TEGD. The cytosol fraction of the homogenate was obtained in a standard ultracentrifuge $(100,000 \times g$ for $30 \mathrm{~min}$ ), and the levels of $\mathrm{E}_{2}$ receptors were determined as described. We also used pooled MBH-POA cytosol to determine the protein concentrations over which the amount of $\mathrm{E}_{2}$ receptor varied linearly with the amount of protein. This was done by incubating $1 \mathrm{nM}\left[{ }^{3} \mathrm{H}\right] \mathrm{E}_{2}$ with varying amounts of cytosol from DMSO-perfused and frozen tissue.

\section{Results}

Scatchard analysis and linearity. Scatchard analysis revealed that there was a moderate loss in the number of $\mathrm{E}_{2}$ receptors in frozen, DMSO-perfused MBH-POA as compared to unfrozen tissue ( $B_{\max }$ for unfrozen tissue, $23.6 \pm 4.3 ; B_{\max }$ for frozen tissue, $15.1 \pm 2.6$ ), but there was no change in the affinity of receptors after freezing (fresh $K_{d}, 0.44 \pm 0.01 \mathrm{nM}$; frozen $K_{d} ; 0.48 \pm .03 \mathrm{nM}$, mean \pm SEM, $n=3$ ). This indicated that substantial amounts of $\mathrm{E}_{2}$ receptor was preserved during the freezing and thawing process. In preliminary studies, we observed only slightly higher levels (10 to $20 \%$ ) of $\mathrm{E}_{2}$ receptor in samples microdissected from DMSO-perfused tissue compared to samples from unperfused frozen tissue. This indicated that the DMSO perfusion had only a slightly protective effect on freezing-induced loss in our samples in contrast to its larger cryoprotective action on pituitary $\mathbf{E}_{2}$ receptors and neural progestin receptors (MacLusky et al., 1982; Parsons et al., 1982).

The amount of $\mathrm{E}_{2}$ receptor was proportional to the amount of cytosol protein over concentrations from 5 to $200 \mu \mathrm{g}$. The protein content of all nuclei and subregions was within this range (Table I). In areas with moderate amounts of receptor, about $40 \mu \mathrm{g}$ of cytosol protein (120 $\mu \mathrm{g}$ of homogenate protein) was needed to obtain reliable measurements of $\mathbf{E}_{2}$ binding ( $20 \mu \mathrm{g}$ for total binding and $20 \mu \mathrm{g}$ for nonspecific binding). It was sufficient to use only $10 \mu \mathrm{g}$ of cytosol protein in regions with a high density of receptor. Depending on the density of receptor, the amount of specific binding for $\left[{ }^{3} \mathrm{H}\right] \mathrm{E}_{2}$ ranged from 20 to $80 \%$ of the total binding.

Distribution of $E_{2}$ receptor in brain regions. There were significant levels of cytoplasmic $\mathbf{E}_{2}$ receptors in most of the 46 brain regions that we examined (Table II). In agreement with previous biochemical and autoradiographic studies (McEwen and Pfaff, 1970; Pfaff and Keiner, 1973), the highest levels of receptor were found in nuclei of the mediobasal hypothalamus and preoptic area. There were low to moderate levels of $\mathrm{E}_{2}$ receptors in certain regions of the limbic system and diencephalon, and there were also regions of the rat brain, such as the caudate-putamen, that lacked measurable amounts of $\mathrm{E}_{2}$ receptor. 
TABLE I

Location and protein content of nuclei and subregions in $300-\mu \mathrm{m}$ frozen sections

The location and protein content of nuclei and subregions within frozen sections and the size of punch cannula used for removal are given. Three hundred-micrometer-thick coronal sections of rat brain were cut with a cryostat and thaw-mounted onto glass slides. Nuclei and subregions were removed according to the procedure of Palkovits (1973) using a 500- or $1000-\mu \mathrm{m}$ stainless steel cannula or with a small scalpel. Sections were cut in consecutive $300-\mu \mathrm{m}$ intervals. Section 1 corresponed to König and Klippel's (1963) level A8380. Section 2 is 300$\mu \mathrm{m}$ posterior to section 1 , section 3 is $300 \mu \mathrm{m}$ posterior to section 2 , etc. The protein content of the assay samples was measured by the method of Bradford (1976). The values given in the table are the amounts of protein applied to LH-20 columns and represent four to six experiments; three rats were used per experiment.

\begin{tabular}{|c|c|c|c|}
\hline Region & Section & Punch Size & $\begin{array}{c}\text { Protein per } \\
\text { Assay } \\
\text { Sample }\end{array}$ \\
\hline & & & $\mu g$ \\
\hline Diagonal band of Broca & $1-3$ & $\begin{array}{l}\text { Medial, } 1000 \mu \mathrm{m} \text {; bi- } \\
\text { lateral, } 500 \mu \mathrm{m}\end{array}$ & $27 \pm 4$ \\
\hline Medial septum & $1-3$ & Single, $1000 \mu \mathrm{m}$ & $17 \pm 2$ \\
\hline Lateral septum & $1-3$ & Bilateral, $1000 \mu \mathrm{m}$ & $14 \pm 1$ \\
\hline Olfactory tubercle ${ }^{\alpha}$ & $1-3$ & Bilateral, scalpel & $105 \pm 11$ \\
\hline Nucleus stria terminalis & 3,4 & $\begin{array}{l}\text { Bilateral, } 500 \mu \mathrm{m} \\
\text { above and below } \\
\text { anterior commis- } \\
\text { sure }(3) \text {; bilateral, } \\
1000 \mu \mathrm{m}(4)\end{array}$ & $23 \pm 4$ \\
\hline Medial & 4,5 & Bilateral, $1000 \mu \mathrm{m}$ & $24 \pm 4$ \\
\hline $\begin{array}{l}\text { Suprachiasmatic preop- } \\
\text { tic nucleus }\end{array}$ & 4,5 & Bilateral, $500 \mu \mathrm{m}$ & $8 \pm 2$ \\
\hline $\begin{array}{l}\text { Periventricular preoptic } \\
\text { nucleus }\end{array}$ & 4,5 & $\begin{array}{l}\text { Scalpel, } 250 \mu \mathrm{m} \\
\quad \text { around ventricle }\end{array}$ & $12 \pm 1$ \\
\hline Lateral preoptic nucleus & 4,5 & Bilateral, $1000 \mu \mathrm{m}$ & $32 \pm 3$ \\
\hline Cau & $4-6$ & Bilateral, $1000 \mu \mathrm{m}$ & $35 \pm 3$ \\
\hline Parietal c & $4-7$ & Bilateral, scalpel & $173 \pm 11$ \\
\hline Cingulate cortex & $4-7$ & Scalpel & $170 \pm 3$ \\
\hline $\begin{array}{l}\text { Periventricular anterior } \\
\text { hypothalamus }\end{array}$ & $6-9$ & $\begin{array}{l}\text { Scalpel or single, } \\
1000 \mu \mathrm{m}\end{array}$ & $17 \pm 2$ \\
\hline Anterior hypothalamus & $6-9$ & Bilateral, $1000 \mu \mathrm{m}$ & $37 \pm 5$ \\
\hline & $6-8$ & Bilateral, $500 \mu \mathrm{m}$ & $7 \pm 1$ \\
\hline acleus & $8-10$ & Single, $1000 \mu \mathrm{m}$ & $19 \pm 2$ \\
\hline Ventromedial $n$ & $10-14$ & Bilateral, $1000 \mu \mathrm{m}$ & $60 \pm 2$ \\
\hline Dorsomedial nucleus & $11-14$ & Bilateral $1000 \mu \mathrm{m}$ & $53 \pm 2$ \\
\hline $\begin{array}{l}\text { Arcuate-median emi- } \\
\text { nence }^{b}\end{array}$ & $11-14$ & Scalpel & $51 \pm 2$ \\
\hline hypothalamus & $11-14$ & $\mathrm{~L}, 1000 \mu \mathrm{m}$ & $46 \pm 6$ \\
\hline Medi & $11-14$ & Bilateral, $1000 \mu \mathrm{m}$ & $60 \pm 4$ \\
\hline Cortic & $11-14$ & Bilateral, $1000 / \mathrm{m}$ & $60 \pm 2$ \\
\hline Ventr & $11-14$ & Bilateral, $1000 \mu \mathrm{m}$ & $44 \pm 5$ \\
\hline Reun & $11-14$ & Single, $1000 \mu \mathrm{m}$ & $24 \pm 4$ \\
\hline Khon & $11-14$ & Single, $500 \mu \mathrm{m}$ & $12 \pm 3$ \\
\hline Dentate gyrus & $12-15$ & $\begin{array}{l}\text { Bilateral, } 2 \times 500 \\
\mu \mathrm{m}\end{array}$ & $28 \pm 3$ \\
\hline $\mathrm{CA}_{1}$ & $12-15$ & $\begin{array}{l}\text { Bilateral, } 2 \times 500 \\
\mu \mathrm{m}\end{array}$ & $27 \pm 2$ \\
\hline $\mathrm{CA}$ & $12-15$ & Bilateral, $1000 \mu \mathrm{m}$ & $43 \pm 3$ \\
\hline Do & $12-15$ & Bilateral, $500 \mu \mathrm{m}$ & $15 \pm 3$ \\
\hline Habenula & $15-$ & Bilateral, $1000 \mu \mathrm{m}$ & $35 \pm 1$ \\
\hline $\begin{array}{l}\text { Ventral premammillary } \\
\text { nucleus }\end{array}$ & 15,16 & Bilateral, $1000 \mu \mathrm{m}$ & $30 \pm 1$ \\
\hline Ventral subiculum & $22-25$ & Bilateral, $1000 \mu \mathrm{m}$ & 56 上 7 \\
\hline Central grey & $22-27$ & Single, $1000 \mu \mathrm{m}$ & $43 \pm 4$ \\
\hline
\end{tabular}

"The sample of the olfactory tubercle included all three cell layers (plexiform, pyramidal, and polymorphic (Krieger, 1981)).

${ }^{b}$ The arcuate nucleus could not be removed consistently without taking some of the median eminence; therefore, this sample must be considered as a pool of the two regions.
'I'ABLE' II

Estrogen $\left(E_{2}\right)$ receptor levels in nuclei and subregions

The values are measurements of cytoplasmic $\mathrm{E}_{2}$ receptor levels in nuclei and subregions of rat brain. The amount of $\mathrm{E}_{2}$ receptor in microdissected regions of rat brain was measured as described in the text. Tissue from three rat brains was pooled for one assay. $N$ is the number of assays. Results are expressed as femtomoles per $\mathbf{m g}$ of $\mathbf{E}_{2}$ specifically bound per $\mathrm{mg}$ of cytosol protein \pm SEM. The total counts per min per sample ranged from 50 to $100 \mathrm{cpm}$ above background in regions with a high concentration of $\mathrm{E}_{2}$ receptors (Fig. 1) and 20 to 50 $\mathrm{cpm}$ in areas with zero to moderate amount of $\mathrm{E}_{2}$ receptor. The nonspecific counts per min ranged from 10 to $35 \mathrm{cpm}$. The background was $7 \mathrm{cpm}$. All samples were counted for a minimum of $10 \mathrm{~min}$. The amount of cytosol protein used in one assay is given in Table I. Statistical significance was assessed with a two-tailed Student's $t$ test. All receptor levels are significantly $(p<0.05)$ different from zero unless footnoted.

\begin{tabular}{|c|c|c|}
\hline Region & Amount & $N$ \\
\hline & fmol/mg protein & \\
\hline Diagonal band of Broca & $2.8 \pm 0.7$ & 4 \\
\hline Medial septum & N.S. ${ }^{a}$ & 6 \\
\hline Lateral septum & $1.8 \pm 0.8$ & 6 \\
\hline Olfactory tubercle & $2.2 \pm 0.4$ & 4 \\
\hline Nucleus stria terminalis & $6.1 \pm 1.3$ & 6 \\
\hline Medial preoptic nucleus & $21.6 \pm 4.9$ & 6 \\
\hline Suprachiasmatic preoptic nucleus & $13.2 \pm 2.9$ & 4 \\
\hline Periventricular preoptic area & $32.0 \pm 1.0$ & 6 \\
\hline Lateral preoptic nucleus & $1.9 \pm 0.8$ & 5 \\
\hline Caudate-putamen & N.S. ${ }^{a}$ & 4 \\
\hline Parietal cortex & N.S. ${ }^{a}$ & 6 \\
\hline Cingulate cortex & $1.4 \pm 0.2$ & 4 \\
\hline Periventricular anterior hypothalamus & $18.5 \pm 1.3$ & 6 \\
\hline Antcrior hypothalamus & $6.7 \pm 2.5$ & 5 \\
\hline Supraoptic nucleus & $8.6 \pm 1.7$ & 6 \\
\hline Paraventricular nucleus & $6.5 \pm 1.0$ & 5 \\
\hline Ventromedial nucleus & $12.0 \pm 1.7$ & 6 \\
\hline Dorsomedial nucleus & $4.9 \pm 0.7$ & 6 \\
\hline Arcuate-median eminence & $13.4 \pm 1.7$ & 6 \\
\hline Lateral hypothalamus & $4.2 \pm 1.0$ & 4 \\
\hline Medial amygdala & $9.8 \pm 1.7$ & 6 \\
\hline Cortical amygdala & $3.4 \pm 0.5$ & 6 \\
\hline Ventral thalamus & N.S. ${ }^{a}$ & 5 \\
\hline Reuniens nucleus & N.S. ${ }^{a}$ & 4 \\
\hline Rhomboid nucleus & $2.4 \pm 1.4$ & 5 \\
\hline Dentate gyrus & $3.0 \pm 1.3$ & 5 \\
\hline $\mathrm{CA}_{1}$ & N.S. ${ }^{a}$ & 5 \\
\hline $\mathrm{CA}_{3}$ & N.S. ${ }^{a}$ & 5 \\
\hline Dorsal subiculum & N.S. ${ }^{a}$ & 4 \\
\hline Habenula & $1.3 \pm 0.6^{b}$ & 4 \\
\hline Ventral premammillary nucleus & $5.4 \pm 1.5$ & 4 \\
\hline Ventral subiculum & $2.4 \pm 0.9$ & 4 \\
\hline Central grey & N.S. ${ }^{a}$ & 4 \\
\hline
\end{tabular}

${ }^{a}$ N.S., not significantly different from a zero level of receptor.

${ }^{b} p=0.056$ compared to $0 \pm 0$.

Mediobasal hypothalamus-preoptic area. 'The highest concentration of cytoplasmic $\mathrm{E}_{2}$ receptors in the brain was found in the nuclei of the preoptic area. Within the POA, the amount of $\mathrm{E}_{2}$ receptor was greatest in the periventricular nucleus ( 30 to $40 \mathrm{fmol} / \mathrm{mg}$ of protein), followed by the medial preoptic nucleus $(20 \mathrm{fmol} / \mathrm{mg})$ and the suprachiasmatic preoptic nucleus $(13 \mathrm{fmol} / \mathrm{mg}$ ). By contrast, the lateral preoptic nucleus had low levels of $E_{2}$ binding $(2 \mathrm{fmol} / \mathrm{mg})$. There were moderate $(6 \mathrm{fmol} /$ $\mathrm{mg}$ ) levels of receptor dorsal to the POA, in the bed nucleus of the stria terminalis, while there was no de- 
tectable receptor immediately lateral to the bed nucleus in the caudate-putamen. There were high levels of $\mathbf{E}_{2}$ receptor $(18 \mathrm{fmol} / \mathrm{mg})$ immediately caudal to the POA in the periventricular nucleus of the anterior hypothalamus (PVAH) with moderate $(6 \mathrm{fmol} / \mathrm{mg}$ ) but significantly lower levels of receptor lateral to the PVAH in the anterior hypothalamic nucleus. There were moderate levels of $\mathrm{E}_{2}$ binding lateral and dorsal to the anterior hypothalamus in the supraoptic and paraventricular nuclei. We also observed high levels $\left(13 \mathrm{fmol} / \mathrm{mg}\right.$ ) oî $\mathbf{E}_{2}$ receptor immediately caudal to the PVAH in pooled tissue from the arcuate nucleus and median eminence. There were also high levels of $\mathbf{E}_{2}$ receptor immediately lateral to the arcuate in the ventromedial nucleus (VMN). The dorsomedial nucleus, immediately above the VMN, had moderate levels of $\mathrm{E}_{2}$ receptor $(5 \mathrm{fmol} /$ $\mathrm{mg}$ ) as did the lateral nucleus of the hypothalamus. The ventral premammillary nucleus, immediately caudal to the VMN, also had moderate levels of receptor.

Limbic regions. There were low (1 to $3 \mathrm{fmol} / \mathrm{mg}$ ) but detectable levels of $\mathrm{E}_{2}$ receptor immediately rostral to the POA in the nucleus of the diagonal band of Broca. The olfactory tubercle, immediately lateral to the diagonal band, also had a low but significant amount of $\mathbf{E}_{2}$ receptor $(2 \mathrm{fmol} / \mathrm{mg})$. There were detectable numbers of binding sites in the lateral septum but no measurable $\mathrm{E}_{2}$ receptor in the medial septum. The cingulate cortex had low but significant amounts of $\mathrm{E}_{2}$ receptor, while there was no apparent receptor in the neighboring parietal cortex. We observed relatively high amounts of $\mathrm{E}_{2}$ receptor in the medial amygdaloid nucleus ( $10 \mathrm{fmol} / \mathrm{mg}$ ), while moderate $(3 \mathrm{fmol} / \mathrm{mg}$ ) but significantly lower amounts of receptor were present in the cortical nucleus of the amygdala. In the hippocampus, there were low but significant amounts of receptor in the dentate gyrus and the ventral subiculum. There was no detectable $\mathrm{E}_{2}$ receptor in the $\mathrm{CA}_{1}$ and $\mathrm{CA}_{3}$ hippocampal subfields nor in the dorsal subiculum.

Diencephalon and midbrain. The midline reuniens nucleus of the thalamus had a low level of $\mathrm{E}_{2}$ binding, while there was no detectable receptor in the rhomboid nucleus immediately dorsal to the reuniens. The ventral thalamic nucleus also lacked measurable $\mathrm{E}_{2}$ receptors. The level of $\mathrm{E}_{2}$ receptor in the habenula approached statistical significance $(p=0.056)$, while no significant receptor was observed in the central grey, an area that shows moderate labeling in $\left[{ }^{3} \mathrm{H} \mathrm{E}_{2}\right.$ autoradiography (Pfaff and Keiner, 1973).

Subregions of $M B H-P O A$ nuclei. The high level of $\mathrm{E}_{2}$ binding in particular MBH-POA nuclei enabled us to assay the amount of receptor in their anatomical subregions (Table III). The bed nucleus of the stria terminalis (Nst) extended over two, 300- $\mu \mathrm{m}$-thick coronal sections, corresponding roughly to König and Klippels (1963) levels A7190 and A6860. There was no significant difference between the amount of receptor in the rostral portion of the Nst (the first 300- $\mu$ m section) and the caudal portion of the nucleus (the second 300- $\mu$ m section). Similarly, the medial preoptic nucleus (MPOA) and the periventricular preoptic nucleus (PVPOA) also extended over two, 300- $\mu \mathrm{m}$ sections. There was no difference in the amount of $\mathrm{E}_{2}$ receptor in the rostral and caudal portions
TABLE III

Estrogen ( $\left.E_{2}\right)$ receptor levels in subdivisions of mediobasal hypothalamic and preoptic nuclei

The nuclei in Table II with the highest concentration of $\mathbf{E}_{2}$ receptor were subdivided into rostral and caudal portions or, in the case of the VMN, into medial and lateral portions as well ( $N=4$ for all regions). The rostral bed nucleus was removed from section 3 (Table I); its caudal portion was removed from section 4 . The rostral medial preoptic nucleus and periventricular preoptic nucleus were removed from section 4 ; their caudal portions were removed from section 5. The rostral periventricular anterior hypothalamus was taken from sections 6 and 7 ; its caudal portion was removed from sections 8 and 9 . The rostral VMN was taken from sections 10 to 12 ; the caudal VMN was removed from sections 13 and 14. The medial and lateral portions of the VMN were removed from sections 10 to 14 . The sizes of the punch cannulas used were the same as in Table I. The medial and lateral VMN were removed bilaterally with a $500-\mu \mathrm{m}$ cannula. The amount of receptor in the caudal portion of the periventricular anterior hypothalamus is significantly different than the amount in the rostral portion $(p<0.05$; paired $t$ test). There were no additional significant differences.

\begin{tabular}{lc}
\multicolumn{1}{c}{ Nucleus } & Ausouni \\
\hline & fmol/mg protein \\
Nucleus stria terminalis, rostral & $8.1 \pm 3.0$ \\
Nucleus stria terminalis, caudal & $10.6 \pm 1.5$ \\
Medial preoptic nucleus, rostral & $10.9 \pm 1.1$ \\
Medial preoptic nucleus, caudal & $23.0 \pm 5.2$ \\
Periventricular preoptic nucleus, rostral & $41.8 \pm 15.0$ \\
Periventricular preoptic nucleus, caudal & $58.0 \pm 22.0$ \\
Periventricular anterior hypothalamus, ros- & $27.0 \pm 3.4$ \\
$\quad$ tral & \\
Periventricular anterior hypothalamus, cau- & $9.7 \pm 1.4$ \\
$\quad$ dal & \\
Ventromedial nucleus, rostral & $15.0 \pm 3.0$ \\
Ventromedial nucleus, caudal & $13.5 \pm 1.2$ \\
Ventromedial nucleus, lateral & $11.6 \pm 4.1$ \\
Ventromedial nucleus, medial & $\mathrm{N.S}{ }^{a}$
\end{tabular}

${ }^{a}$ N.S., not significantly different from a zero level of receptor.

of the PVPOA, and although it appeared that there was more receptor in the caudal portion of the MPOA than in the rostral portion, this difference did not reach statistical significance. The PVAH and the VMN are large nuclei that extend over four and five $300-\mu \mathrm{m}$ sections, respectively. There was no difference in the amount of $\mathrm{E}_{2}$ receptor in the first three sections of the VMN, compared to the last two sections. However, the rostral two sections of the PVAH had significantly more receptor than the caudal sections. It is also possible to divide the VMN into medial and lateral portions. In agreement with $\left[{ }^{3} \mathrm{H}\right] \mathrm{E}_{2}$ autoradiography (Pfaff and Keiner, 1973), there were high levels of $\mathrm{F}_{2}$ receptor in the lateral portion of the VMN and no significant receptor in its medial portion.

\section{Discussion}

Our biochemical measurements of the amount of $\mathrm{E}_{2}$ receptor in rat brain nuclei and subregions are in good agreement with the general pattern of labeling obtained with $\left[{ }^{3} \mathrm{H}\right] \mathrm{E}_{2}$ autoradiography (Stumpf, 1968; Pfaff and Keiner, 1973). Pfaff and Keiner (1973) observed large numbers of labeled cells in the periventricular region extending rostrally through the POA and caudally through the arcuate nucleus. They found less uptake of $\left[{ }^{3} \mathrm{H}\right] \mathrm{E}_{2}$ in nuclei lateral to the periventricular region, and 
there were also many labeled cells in the ventrolateral portion of the VMN and medial nucleus of the amygdala, while less intense but consistent labeling was seen in the diagonal band of Broca, lateral septum, and olfactory tubercle. These observations agree with our measurements (Tables II and III; Fig. 1).

There are also several discrepancies between our results and the autoradiographic studies. There is a moderate $(8 \mathrm{fmol} / \mathrm{mg})$ level of soluble $E_{2}$ receptor in the supraoptic nucleus (SON), while no $\mathrm{E}_{2}$ labeling was observed in the SON with autoradiography (Pfaff and Keiner, 1973). Similarly, there was only a moderate amount of receptor in the caudal portion of the Nst, which, in $\left[{ }^{3} \mathrm{H}\right] \mathrm{E}_{2}$ autoradiograms, appears as intensely labeled as the PVPOA. In addition, there was no detectable $\mathrm{E}_{2}$ receptor in the central grey, a region which shows moderate but reliable labeling of some cells in autoradiography.

There are several possible explanations for the discrepancies between the autoradiographic and biochemical measurements. First, we are measuring only cytoplasmic receptors for $\mathrm{E}_{2}$, while the autoradiographic studies are visualizing both cytoplasmic receptors and nuclear receptors translocated from the cytoplasm by the in vivo administration of $\left[{ }^{3} \mathrm{H}\right] \mathrm{E}_{2}$ (Pfaff and Keiner, 1973). Since only half of the cytoplasmic receptors in pooled $\mathrm{MBH}$ POA tissue move into nuclei in response to $\mathrm{E}_{2}$ (Lieberburg et al., 1980), it is possible that regional differences in the ability of $\mathrm{E}_{2}$ receptors to translocate into nuclei might account for some of the differences between the biochemical and autoradiographic measurements. For example, it is conceivable that the $E_{2}$ receptors in the SON do not translocate as extensively into nuclei in response to the steroid as in the VMN. It is also possible that the amount of cytoplasmic $E_{2}$ receptor varies considerably within individual cells so that a biochemically small level of receptor might be concentrated in a few cells, which appear labeled in autoradiography. This could explain why scattered labeled cells appear in the central grey, while no detectable receptor is seen by biochemical assay. We also observed a moderate loss in $\mathrm{E}_{2}$ receptors from large samples of $\mathrm{MBH}-\mathrm{POA}$ during freezing and cannot exclude the possibility that the extent of the loss differs among nuclei and subregions.

The high levels of $\mathrm{E}_{2}$ receptor in particular $\mathrm{MBH}-\mathrm{POA}$ nuclei, such as the MPOA or the VMN, supports the notion that these regions are important target siles for the actions of $\mathrm{E}_{2}$ on behavior and neuroendocrine function. It is known that direct implants of $\mathrm{E}_{2}$ into the nuclei of the MBH-POA with the highest levels of receptor (MPOA and VMN) will duplicate many of the actions of peripherally administered steroid on reproductive or nonreproductive behaviors (Davis et al., 1979; Rubin and Barfield, 1980; Wade and Zucker, 1970) or on gonadotropin secretion (Goodman, 1978). The ablation of these nuclei (Pfaff and Sakuma, 1979; Taleisnik and McCann,

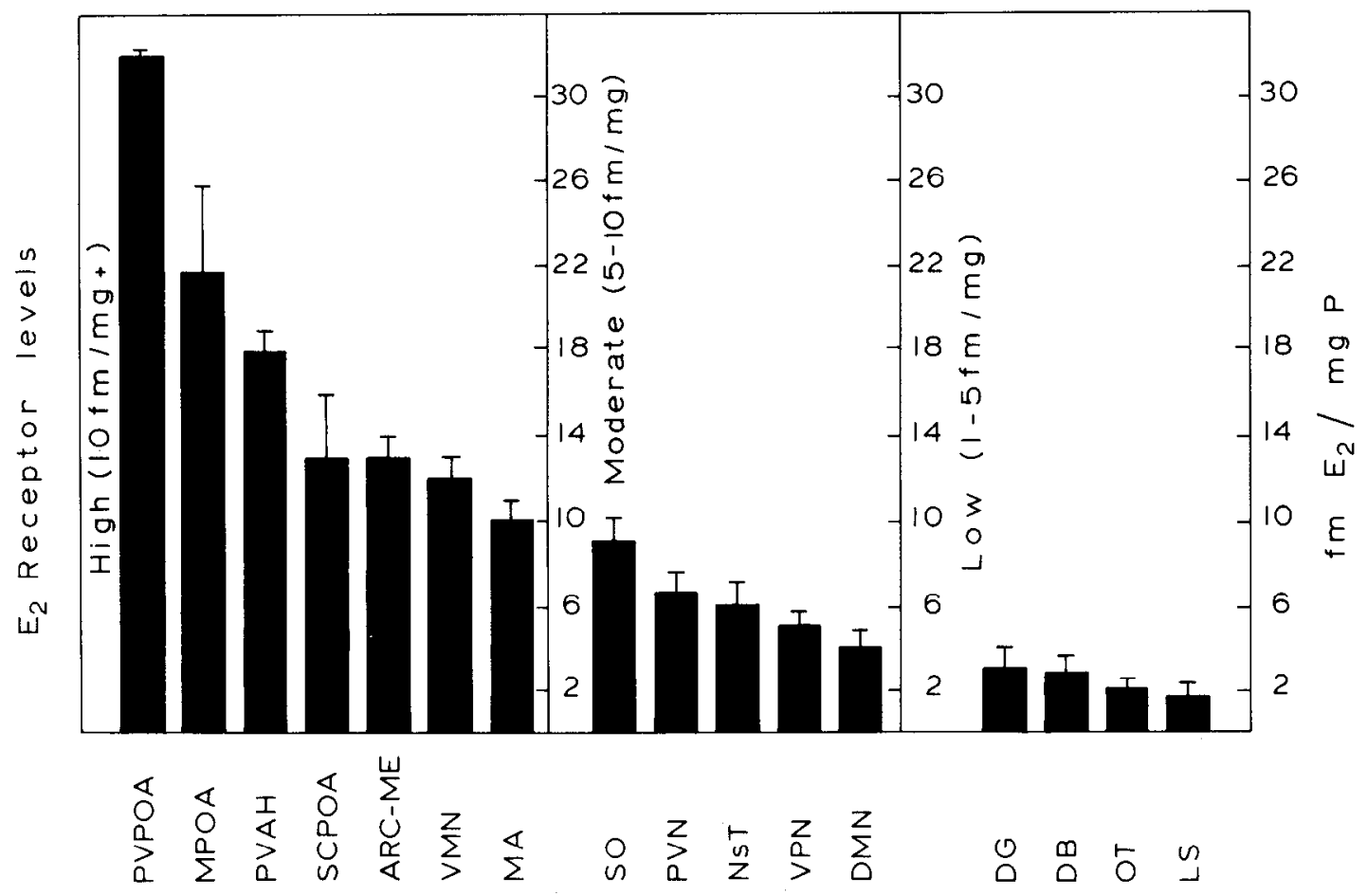

Figure 1. Concentration of $\mathrm{E}_{2}$ receptors in selected nuclei and subregions. The data are from Table II. Results are expressed as femtomoles per $\mathrm{mg}$ of $\mathrm{E}_{2}$ specifically bound per $\mathrm{mg}$ of protein. The abbreviations used are: $P V P O A$, periventricular preoptic area; $M P O A$, medial preoptic area; $P V A H$, periventricular anterior hypothalamus; $S C P O A$, suprachiasmatic preoptic nucleus; ARC-ME, arcuate nucleus-median eminence; $V M N$, ventromedial nucleus; $M A$, medial amygdaloid nucleus; $S O$, supraoptic nucleus; $P V N$, paraventricular nucleus; $N s T$, bed nucleus of the stria terminalis; $V P N$, ventral premammillary nucleus; $D M N$, dorsomedial nucleus; $D G$, dentate gyrus; $D B$, nucleus of the diagonal band of Broca; $O T$, olfactory tubercle; $L S$, lateral septum. 
1961) or disruption of their function with pharmacological inhibitors (Jackson, 1972; Rainbow et al., 1980) also will impair the same behavioral and neuroendocrine effects of $E_{2}$. The functional significance of the moderate and low levels of $E_{2}$ receptors in particular brain regions is more obscure. The presence of moderate levels of $\mathrm{E}_{2}$ receptor in the supraoptic and paraventricular nuclei might provide an explanation for the actions of $E_{2}$ on the secretion of oxytocin and vasopressin (Skowsky et al., 1979; Yamaguchi et al., 1979), the peptide hormones synthesized by these nuclei. The presence of a low level of $\mathrm{E}_{2}$ receptor in subregions of the hippocampus is consistent with the observed changes in hippocampal electrical activity after direct application of $\mathrm{E}_{2}$ to hippocampal slices maintained in vitro (Teyler et al., 1980). These receptors also might mediate a sexually divergent effect of $E_{2}$ that could explain the sexually dimorphic pattern of axonal sprouting observed in the hippocampus (Loy and Milner, 1980). The possible functions of the low and moderate levels of $\mathbf{E}_{2}$ receptors in such regions as the ventral premammillary nucleus or the olfactory tubercle are less apparent. It may be that these receptors mediate currently unknown actions of $\mathrm{E}_{2}$ on the brain.

An important aspect of our study is that it provides a method for the relatively rapid quantification of $\mathrm{E}_{2}$ receptors in individual brain nuclei and subregions. Thus, alterations in whole hypothalamic or limbic $\mathbf{E}_{2}$ receptor levels (Roy and Wilson, 1981; Camp-Grossman and Wise, 1981; Phelps et al., 1981) now can be localized to particular nuclei or subregions. It is also feasible to make quantitative comparisons in the amount of $\mathrm{E}_{2}$ receptor in nuclei of male or female brains (Lieberburg et al., 1980; Nordeen and Yahr, 1981) or between different species. We have used the same methodology to measure the levels of cytoplasmic progestin receptors in nuclei and subregions of rat brain (Parsons et al., 1982b), and it should be possible to extend the method to quantitate receptors for other steroid hormones in neural tissue. It also may be feasible to measure nuclear receptors for steroid hormones in frozen punch-out samples. It is likely that the further biochemical analysis of the receptors for $\mathrm{E}_{2}$ and other steroid hormones at or below the level of individual nuclei will clarify further how steroid hormones affect the brain.

\section{References}

Arai, Y., and R. A. Gorski (1968) Effect of anti-estrogen on steroid induced sexual receptivity in ovariectomized rats. Physiol. Behav. 3: 351-353.

Bradford, M. M. (1976) A rapid and sensitive method for quantitation of microgram quantities of protein utilizing the principle of protein dye-binding. Anal. Biochem. 72: 248-254.

Camp-Grossman, P., and P. M. Wise (1981) Biochemical characteristics of estradiol nuclear receptors in various brain regions of middle-aged female rats: Their possible role in altered $\mathrm{E}_{2}$ positive feedback. Endocrinology Suppl. 108: 478.

Davis, P. G., B. S. McEwen, and D. W. Pfaff (1979) Localized behavioral effects of tritiated estradiol implants in the ventromedial hypothalamus of female rats. Endocrinology 104: 898-903.

Eisenfeld, A. J., and J. Axelrod (1965) Selectivity of estrogen distribution in tissues. J. Pharmacol. Exp. Ther. 150: 469475 .
Goodman, R. L. (1978) The site of the positive feedback action of estradiol in the rat. Endocrinology 102: 151-159.

Jackson, G. L. (1972) Effect of actinomycin D on estrogeninduced release of luteinizing hormone in ovariectomized rats. Endocrinology 91: 1284-1287.

König, J. F. R., and R. A. Klippel (1963) The Rat Brain: A Stereotaxic Atlas, Williams and Wilkins Co., Baltimore.

Krey, L. C., and B. Parsons (1982) Characterization of estrogen stimuli sufficient to initiate cyclic luteinizing hormone release in acutely ovariectomized rats. Neuroendocrinology 34: $315-322$.

Krieger, N. R. (1981) Neurochemistry of the olfactory tubercle. In Biochemistry of Taste and Olfaction, R. Cagan and M. Kara, eds., pp. 417-441, Academic Press, New York.

Labhsetwar, A. P. (1970) The role of oestrogens in spontaneous ovulation: Evidence for positive oestrogen feedback in the 4day oestrous cycle. J. Endocrinol. 47: 481-493.

Lieberburg, I., N. J. MacLusky, and B. S. McEwen (1980) Cytoplasmic and nuclear estradiol $17 \beta$ binding in male and female rat brain: Regional distribution, temporal aspects and metabolism. Brain Res. 193: 487-503.

Loy, R., and T. A. Milner (1980) Sexual dimorphism in extent of axonal sprouting in rat hippocampus. Science 208: 12821283.

MacLusky, N. J., M. Riskalla, E. Roy, and A. Eisenfeld (1982) Preservation of the steroid receptor in frozen brain and pituitary tissue: Use of the cryoprotective agent, dimethylsulfoxide. J. Neurosci. Methods, submitted.

McEwen, B. S. (1978) Gonadal steroid receptors in neuroendocrine tissues. In Hormone Receptors. Vol. I: Steroid Hor mones, pp. 353-400, Academic Press, New York.

McEwen, B. S., and D. W. Pfaff (1970) Factors influencing sex hormone uptake by rat brain regions: I. Effects of neonatal treatment, hypophysectomy, and competing steroid on estradiol uptake. Brain Res. 21: 1-16.

McEwen, B. S., D. W. Pfaff, C. Chaptal, and V. Luine (1975) Brain cell nuclear retention of ${ }^{3} \mathrm{H}$-estradiol doses able to promote lordosis: Temporal and regional aspects. Brain Res. 86: $155-161$.

McGinnis, M. Y., L. C. Krey, N. J. MacLusky, and B. S. McEwen (1981) Characterization of steroid receptor levels in intact and ovariectomized estrogen-treated rats: An examination of the quantitative, temporal and endocrine factors which influence the neuroendocrine efficacy of an estradiol stimulus. Neuroendocrinology 33: 157-161.

Nordeen, E. J., and P. Yahr (1981) A regional analysis of neural changes related to masculinization and defeminization. Soc. Neurosci. Abstr. 7: 722.

Palkovits, M. (1973) Isolated removal of hypothalamic or other brain nuclei of the rat. Brain Res. 59: 449-450.

Palkovits, M. (1977) Utmutato es atlasz patkanyagy sejtcsoportjainak izolalt kivetelere, Akadémiai Kaidó, Budapest.

Parsons, B., T. C. Rainbow, D. W. Pfaff, and B. S. McEwen (1981) A discontinuous schedule of oestradiol binding in rat hypothalamus is sufficient to activate lordosis behavior and to increase cytosol progestin receptors. Nature 292: 58-59.

Parsons, B., B. S. McEwen, and D. W. Pfaff (1982a) A discontinuous schedule of estradiol treatment is sufficient to activate progesterone-facilitated feminine sexual behavior and to increase cytosol receptors for progestins in the hypothalamus of the rat. Endocrinology 110: 613-619.

Parsons, B., T. C. Rainbow, N. J. MacLusky, and B. S. McEwen (1982b) Progestin receptor levels in rat hypothalamic and limbic nuclei. J. Neurosci. 2: 1446-1452.

Pfaff, D. W., and M. Keiner (1973) Atlas of estradiol-concentrating cells in the central nervous system of the female rat. J. Comp. Neurol. 151: 121-158.

Pfaff, D. W., and Y. Sakuma (1979) Deficit in the lordosis reflex 
of female rats caused by lesions in the ventromedial nucleus of the hypothalamus. J. Physiol. (Lond.) 288: 203-210.

Phelps, C. P., M. Y. McGinnis, D. M. Nance, and B. S. McEwen (1981) Estrogen and progestin receptor binding in brain and pituitary after retrochiasmatic knife cuts. Soc. Neurosci. Abstr. 7: 722.

Rainbow, T. C., P. G. Davis, M. McGinnis, and B. S. McEwen (1980) Application of anisomycin to the lateral ventromedial nucleus blocks the activation of sexual behavior by estradiol and progesterone. Soc. Neurosci. Abstr. 4: 862.

Roy, E. J., and G. N. Wade (1977) Binding of $\left({ }^{3} \mathrm{H}\right)$ estradiol by brain cell nuclei and female rat sexual behavior: Inhibition by antiestrogens. Brain Res. 126: 73-87.

Roy, E. J., and M. A. Wilson (1981) Diurnal rhythm of cytoplasmic estrogen receptors in the rat brain in the absence of circulating estrogens. Science 213: 1525-1527.

Rubin, B. S., and R. J. Barfield (1980) Priming of estrous responsiveness by implants of $17 \beta$ estradiol in the ventromedial hypothalamic nucleus of female rats. Endocrinology
106: 504-509.

Skowsky, W. R., L. Swan, and P. Smith (1979) Effects of sex steroid hormones on arginine vasopressin in intact and castrated male and female rats. Endocrinology 104: 105-108.

Stumpf, W. E. (1968) Estradiol-concentrating neurons: Topography in the hypothalamus by dry mount autoradiography. Science 162: 1001-1003.

Taleisnik, S., and S. M. McCann (1961) Effects of hypothalamic lesions on the secretion and storage of hypophysial luteinizing hormone. Endocrinology 68: 263-272.

Teyler, T. J., R. M. Vardaris, D. Lewis, and A. B. Rawitch (1980) Gonadal steroids: Effect on excitability of hippocampal pyramidal cells. Science 209: 1017-1019.

Wade, G., and I. Zucker (1970) Modulation of food intake and locomotor activity in female rats by diencephalic hormone implants. J. Comp. Physiol. Psychol. 72: 328-336.

Yamaguchi, K., T. Akaishi, and H. Negro (1979) Effect of estrogen treaiment on plasma oxytocin and vasopressin in ovariectomized rats. Endocrinol. Jpn. 26: 197-205. 